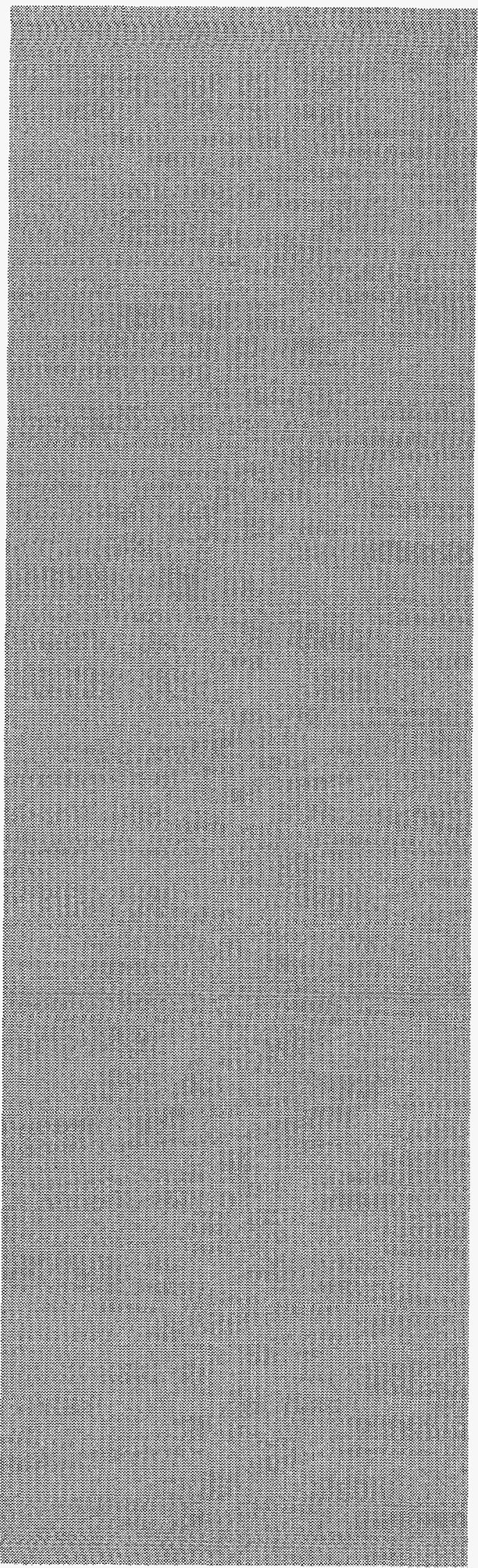

\title{
Design of a New Portable Fork Detector for Research Reactor Spent Fuel
} for the United States Department of Energy under contract W-7405-ENG-36. 
Edited by Paul W. Henriksen, Group CIC-1

Prepared by Celina M. Ortiz, Group NIS-5

This work was supported by the International Safeguards Division (NN-44) of the Office of Arms Control and Nonproliferation, Department of Energy.

An Affirmative Action/Equal Opportunity Employer

This report was prepared as an account of work sponsored by an agency of the United States Government. Neither The Regents of the University of California, the United States Government nor any agency thereof, nor any of their employees, makes any warranty, express or implied, or assumes any legal liability or responsibility for the accuracy, completeness, or usefulness of any information, apparatus, product, or process disclosed, or represents that its use would not infringe privately owned rights. Reference herein to any specific commercial product, process, or service by trade name, trademark, manufacturer, or otherwise, does not necessarily constitute or imply its endorsement, recommendation, or favoring by The Regents of the University of California, the United States Government, or any agency thereof. The views and opinions of authors expressed herein do not necessarily state or reflect those of The Regents of the University of California, the United States Government, or any agency thereof. 


\section{DISCLAIMER}

Portions of this document may be illegible in electronic image products. Images are produced from the best available original document. 
Design of a New Portable Fork Detector for

Research Reactor Spent Fuel

\section{S. -T. Hsue}

H. O. Menlove

P. M. Rinard

\section{Los Alamos}

NAT I ONAL LABORATORY

Los Alamos, New Mexico 87545 


\section{Contents}

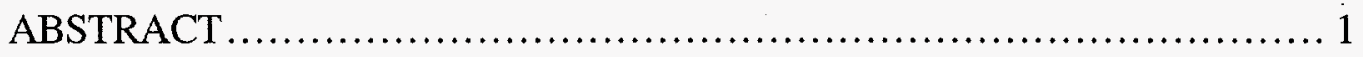

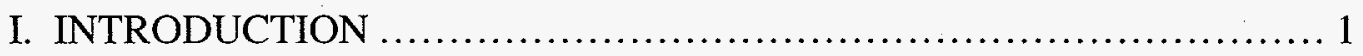

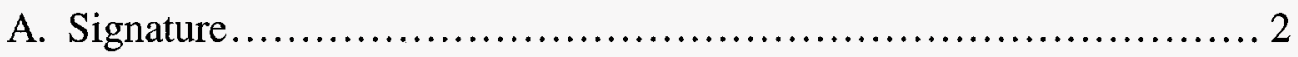

B. Gamma-Ray Detection ........................................... 2

C. Neutron Detection.............................................. 2

II. CONCEPTUAL DESIGN ........................................... 3

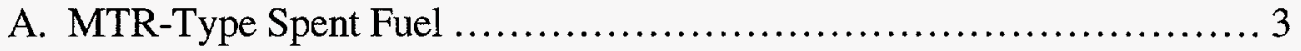

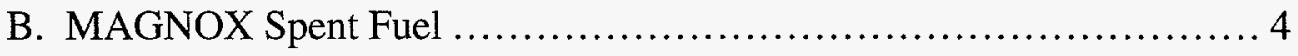

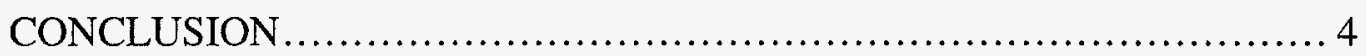

APPENDIX: BURNUP CODE ANALYSIS ............................... 6

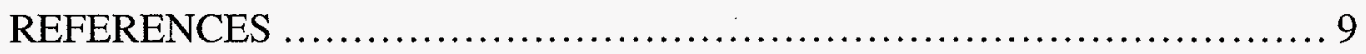




\title{
DESIGN OF A NEW PORTABLE FORK DETECTOR FOR RESEARCH REACTOR SPENT FUEL
}

\author{
by
}

\author{
S. -T. Hsue, H. O. Menlove, and P. M. Rinard
}

\begin{abstract}
This report describes the conceptual design of a new fork detector to verify spent research-reactor fuel. The detector can be used to determine the fissile content of Material Testing Reactor spent fuel or the plutonium content of spent MAGNOX fuel. The detector determines the burnup by means of neutron counting, the gross gamma radiation, and medium-resolution spectroscopy from a room-temperature detector.
\end{abstract}

\section{INTRODUCTION}

There are many situations in nonproliferation and international safeguards when one needs to verify spent research-reactor fuel. Special inspections, a reactor coming under safeguards for the first time, and failed surveillance are prime examples. Several years ago, Los Alamos developed the FORK detector ${ }^{1}$ for the IAEA and EURATOM. This detector, together with the GRAND electronics package, is used routinely by inspectors to verify light-water-reactor spent fuels. Both the FORK detector and the GRAND electronics technologies have been transferred and are now commercially available. Recent incidents in the world indicate that research-reactor fuel is potentially a greater concern for proliferation than light-water-reactor fuels. A device similar to the FORK/GRAND should be developed to verify research-reactor spent fuels because the signals from light-water-reactor spent fuel are quite different than those from research-reactor fuels.

There are two dominant types of research reactors. The first is the Material Testing Reactor (MTR). In the US, the MTR fuel is made from uranium-aluminum alloy with aluminum cladding; the uranium enrichment ranges from $20 \%$ to $93 \%$. The fuel plates are shaped like venetian blind blades and welded into an assembly. Because of the relatively high enrichment, water is used as moderator and the burnup can be as high as $\sim 30 \%$. MTR reactors designed by other countries use fuels of the same material but different geometrical configuration. The second research reactor type uses natural or slightly enriched uranium metal fuel. The cladding can be aluminum or magnesium (MAGNOX). The moderator is either graphite or heavy water. The burnup of this fuel, because of the natural enrichment, can only reach $\sim 1500 \mathrm{MWd} / \mathrm{tU}$.

This project was supported by the International Safeguards Division (NN-44) of the Office of Arms Control and Nonproliferation, Department of Energy. The purpose of the project is to 
develop the conceptual design of a more portable spent fuel assay device. This system, if fully developed, can be used to verify spent research-reactor fuels coming to the United States. The same system, because of its portability, can also be used to verify spent fuels in foreign countries.

\section{A. Signature}

The passive signals from these spent fuels can be gamma rays or neutrons and can be used to determine the burnup. The gamma signal comes mainly from the fission products. The fission products normally observed in spent fuel, after a few months cooling, are ${ }^{95} \mathrm{Zr},{ }^{95} \mathrm{Nb},{ }^{106} \mathrm{Ru}-\mathrm{Rh}$, ${ }^{134} \mathrm{Cs},{ }^{137} \mathrm{Cs},{ }^{144} \mathrm{Ce}-\mathrm{Pr}$, and ${ }^{154} \mathrm{Eu}$. Cesium-137 and ${ }^{134} \mathrm{Cs} /{ }^{137} \mathrm{Cs}$ have been shown to be proportional to burnup. The neutron output of irradiated fuel comes from the even isotopes of plutonium and, depending on the burnup, from ${ }^{242} \mathrm{Cm}$ and ${ }^{244} \mathrm{Cm}$.

The fissile content of these fuels can be determined by active interrogation, and because the radiation field of these spent fuels is in general an order of magnitude lower than the field from light-water-reactor fuels, a simple interrogation system can be designed. Active interrogation has the advantage that it is determining the fissile content rather than an indirect indicator such as burnup. In addition, calibration for active interrogation is relatively simple; an unirradiated fuel element with a good pedigree can be used for calibration.

\section{B. Gamma-Ray Detection}

The gamma rays from the fission product isotopes have energies ranging from $600 \mathrm{keV}$ to $2200 \mathrm{keV}$. The main isotopes of interest are ${ }^{134} \mathrm{Cs}$ and ${ }^{137} \mathrm{Cs}$, which can be used to determine the burnup. Other fission product isotopes, if they can be measured, can be used to determine the cooling time.

For gamma-ray spectroscopy, the best energy resolution is achieved using a high-purity germanium detector. However, germanium detectors require cooling to liquid-nitrogen temperatures, which makes the system impractical to use in spent fuel applications. Other room temperature detectors have been investigated: $\mathrm{HgI}_{2}, \mathrm{CdTe}$, and more recently, $\mathrm{CdZnTe}$. The spectral performances of these detectors have been improved by two recent developments. The main reason for the poor performance is the poor collection efficiency for holes due to intrinsically low hole mobilities and the presence of high concentrations of hole trapping defects. Lawrence Berkeley Laboratory ${ }^{2}$ has developed coplanar electrodes emulating the Frisch grids. This has greatly improved the $\mathrm{CdZnTe}$ detector to measure high-energy photons and reduced the Compton continuum. The other development is the cooling of the CdTe detector by means of Peltier cooling and pulse-rise-time-discrimination electronics. ${ }^{3}$ The Peltier cooling is sufficient to cool the detector to -40 to $-50^{\circ} \mathrm{C}$. The temperature reduces the dark current so that it contributes only slightly to the energy resolution. At the present time, the cooled detector has sufficient resolution to determine the ${ }^{137} \mathrm{Cs},{ }^{134} \mathrm{Cs}$, and ${ }^{144} \mathrm{Pr}$ gamma-ray peaks and can be used to determine burnup and cooling time.

\section{Neutron Detection}

For the measurement of neutrons from research reactor spent fuel, a relatively high detection efficiency is needed because of the low emission rate. It is desirable to use ${ }^{3} \mathrm{He}$ detectors in place of the standard ${ }^{235} \mathrm{U}$ fission chambers because the ${ }^{3} \mathrm{He}$ detector efficiency is approximately 30 
times greater than that of a fission chamber. However, ${ }^{3} \mathrm{He}$ tubes cannot operate in the highgamma fields associated with spent fuel. Traditional ${ }^{3} \mathrm{He}$ tubes were limited to gamma fields in the range of 1-2 R/h unless massive shielding was used. We are developing ${ }^{3} \mathrm{He}$ gas mixtures (in cooperation with Reuter-Stokes) and preamplifiers to extend the ${ }^{3} \mathrm{He}$ tube operating range out to $\sim 500 \mathrm{R} / \mathrm{h}$. This should make it possible to measure the neutron emission from low-burnup reactor fuel with more efficient and portable detector systems.

\section{CONCEPTUAL DESIGN}

After studying the gamma-ray detector and neutron detector, we have arrived at a conceptual design of a new FORK detector. The FORK detector can be installed in a spent-fuel cooling pool. The existing GRAND electronics for the light water reactor FORK can be used. The new design is intended to be used for both MTR and MAGNOX research reactor spent fuel.

\section{A. MTR-Type Spent Fuel}

For MTR-type fuel, the initial fuel is high-enriched uranium, $20 \%$ to $93 \% 235 \mathrm{U}$, and the spent fuel contains very little plutonium. The primary safeguards issue is to verify that the $235 \mathrm{U}$ has not been diverted.

To directly verify the $235 \mathrm{U}$, active neutron interrogation techniques are needed. We are evaluating a portable version of a new active-neutron technique that uses low-energy interrogation from an AmLi neutron source. Figure 1 shows a conceptual diagram of a FORK-type detector head where the fission chambers of the original FORK detector have been replaced by ${ }^{3} \mathrm{He}$ tubes for higher efficiency. An AmLi neutron source has been added to the base of the FORK to induce fissions in the MTR element. The induced fission neutrons are distinguished from the interrogation

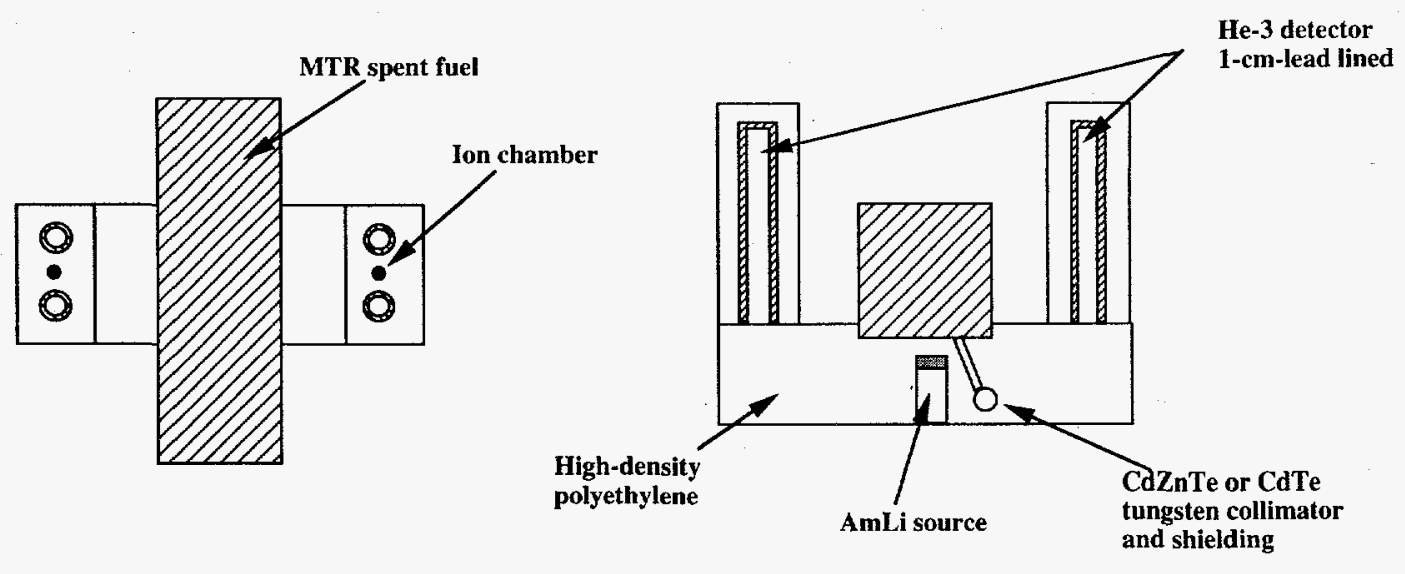

Side View

Top View

Fig. 1. Portable spent-fuel assay system interrogating an MTR spent-fuel assembly. 
neutrons using either coincidence counting, similar to the neutron collar, or a differential transmission method. This differential transmission method uses the higher energy (av $\sim 1.5 \mathrm{MeV}$ ) of the induced fission neutrons compared with the lower energy ( $a v \sim 0.3 \mathrm{keV}$ ) AmLi neutrons. The further the ${ }^{3} \mathrm{He}$ detectors are from the sample, the higher the signal/background ratio in the FORK because the high-energy neutrons have less attenuation in the water than the low-energy AmLi neutrons.

The ion chambers are used to detect gross gamma radiation. They can be used to rapidly determine the burnup profile of the assembly. The CdZnTe or the CdTe detector can be used to determine the burnup from the ${ }^{134} \mathrm{Cs} /{ }^{137} \mathrm{Cs}$ ratio and cooling time from the ${ }^{144} \mathrm{Pr} / 137 \mathrm{Cs}$ ratio.

MTR spent fuel with different geometries can be assayed with this FORK. A different fuel holding attachment may be added to accommodate a different geometry of spent fuel.

The active-neutron interrogation can be calibrated by using a fresh fuel element with good pedigree. The calibration for the gross gamma and ${ }^{134} \mathrm{Cs} /{ }^{137} \mathrm{Cs}$ ratio is much more difficult; in most cases it is a relative measurement and provides a consistency check between measured signal and declared burnup.

\section{B. MAGNOX Spent Fuel}

The MAGNOX-type spent fuel has an initial loading of natural uranium and a low total burnup. Thus, the primary source of passive neutron emission is the ${ }^{240} \mathrm{Pu}$, and the passive neutron count can be used to directly verify the plutonium. However, because of the low neutron emission rates, higher-efficiency neutron detectors are needed. Helium-3 detectors are used in place of the standard ${ }^{235} \mathrm{U}$ fission chambers because the ${ }^{3} \mathrm{He}$ detector efficiency is approximately 30 times larger than that of a fission chamber. One $\mathrm{cm}$ of lead shielding is provided in this design, which will reduce the gamma-ray dosage at $700 \mathrm{keV}$ by a factor of three.

Figure 2 shows a diagram of a FORK-type detector head where the AmLi neutron source has been removed because the fissile content of these fuels is relatively low and the primary source of neutron emission is ${ }^{240} \mathrm{Pu}$. If we just place the MAGNOX fuel at the same location as the MTR fuel, the neutrons may be over-moderated; a steel can has been added to displace water and to position the fuel.

The passive neutron counting of the system can be calibrated with MOX fuel pins with good information on the fissile contents. The neutron emission for the low-burnup fuel is dominated by the plutonium isotopes with a relatively small contribution from ${ }^{242} \mathrm{Cm}$. To determine the plutonium content of the fuel, it is important to correct for the curium, which requires calculating the ${ }^{242} \mathrm{Cm}$ buildup as a function of burnup. In the appendix, we compare the ${ }^{242} \mathrm{Cm}$ calculation from two burnup codes.

\section{CONCLUSION}

This report summarizes the conceptual design of a new fork detector specifically for verifying research reactor spent fuel. This fork can be used to determine the fissile content of MTR spent fuel or the plutonium content of MAGNOX fuel. It can also be used to determine the burnup of the spent fuels. This fork complements the older fork detector designed for light-water-reactor spent fuel assemblies. 


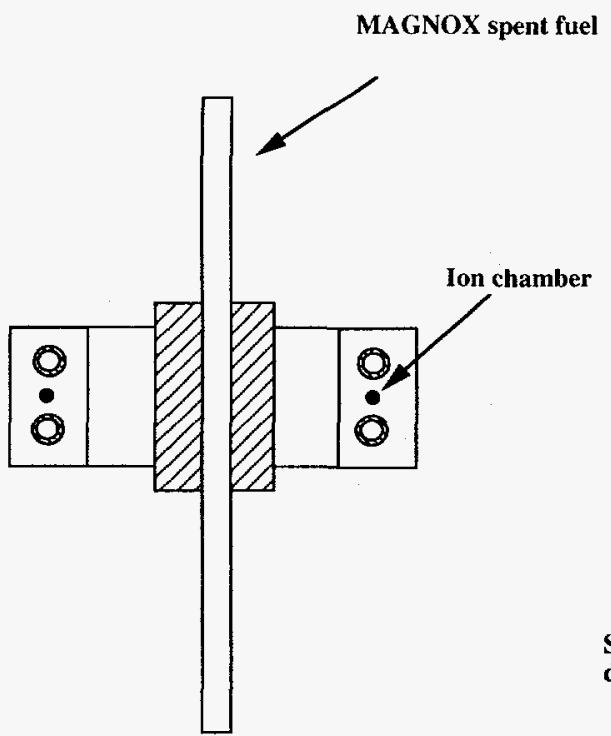

Side View

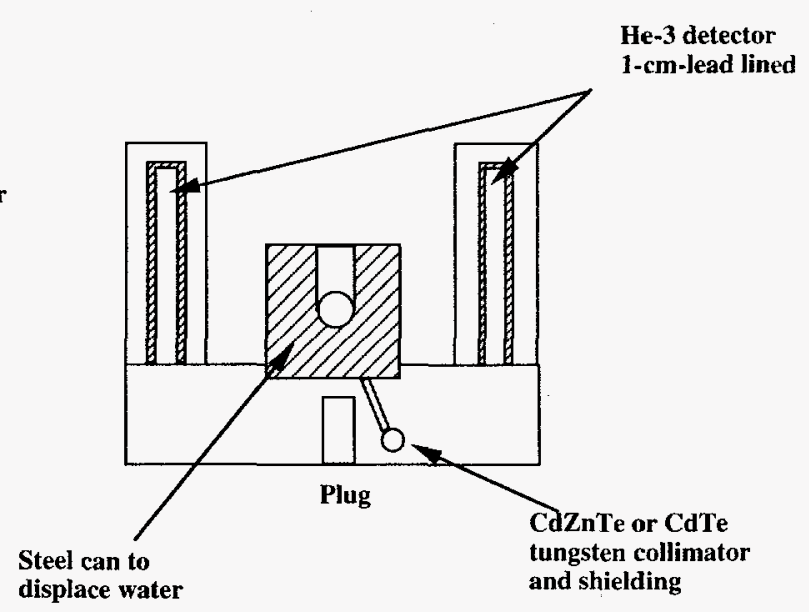

Top View

Fig. 2. Portable spent-fuel assay system assaying a MAGNOX spent-fuel element. 


\title{
APPENDIX: BURNUP CODE ANALYSIS
}

\author{
P. M. Rinard and K. I. Goldman
}

\section{INTRODUCTION}

The passive neutron count rate from a spent-fuel instrument, such as the FORK, is related to the burnup of an assembly through a power law: 4

$$
(\text { total neutron count rate })=\alpha(\text { burnup })^{\beta},
$$

where $\beta$ is about 4 . This simple relation works remarkably well but must be used carefully. The value of $\alpha$ depends strongly on the initial enrichment, so different calibration curves are needed for each enrichment. Furthermore, this power law is likely to have large relative errors for low-burnup assemblies when fitted to data from a set of assemblies that includes high burnups.

The inaccuracy at low burnup is avoided by using the neutron count rate from only the ${ }^{244} \mathrm{Cm}$ nuclide instead of the total from all nuclides and a correction factor $C_{i e}$ for the initial enrichment: ${ }^{5}$

$$
\left({ }^{244} \mathrm{Cm} \text { neutron count rate) } C_{i e}=\alpha \text { (burnup }\right)^{\beta} \text {. }
$$

No measurement device can identify the nuclide from which a neutron originated, so the ${ }^{244} \mathrm{Cm}$ fraction of the total rate must be calculated. The initial enrichment correction factor must also be calculated. These are the roles of a burnup code in the analysis of spent-fuel neutron data.

Safeguards are enhanced by using Eq. (2) because assemblies are compared to a single curve rather than several curves, making it easier to detect incorrectly declared burnups and cooling times.

Some years ago Gene Bosler adapted the Los Alamos CINDER burnup code ${ }^{6-9}$ for use on an IBM-compatible PC. Computers in those days were more limited in memory and speed than today, so CINDER was streamlined by eliminating all capabilities that were not needed to calculate the fraction of the total neutron emission rate that is caused by ${ }^{244} \mathrm{Cm}$. Benchmark calculations were done with both CINDER and CINDER-PC to validate the new version.

The analysis of spent-fuel neutron data was clearly improved by using CINDER-PC and Eq. (2). The calculation of initial enrichment correction factors was built into CINDER-PC for ready application. Not only could a single curve be used for all assemblies (of the same type, such as $17 \times 17$ pressurized water reactor assemblies) regardless of the initial enrichments, the curve passed more accurately through data points at low burnups $(<15 \mathrm{GWd} / \mathrm{tU})$.

\section{RECENT STUDIES}

We discovered that the French safeguards group at the Cadarache Center for Nuclear Studies has gone through a similar evolution, resulting in a PC version of their KAFKA burnup code. The 
LANL and Cadarache parties agreed to compare the results of the two codes as part of a bilateral agreement on the exchange of safeguards technical data.

A set of 27 irradiation cases was selected to cover a range of initial enrichments, burnups, and power histories. The initial enrichments were $1.8 \%, 2.6 \%$, and 3.3\%. The burnups were 15, 30, and $45 \mathrm{GWd} / \mathrm{tU}$. The "standard" power history had three cycles at full power, separated by a month at zero power and followed by 495 days of cooling. The "long intercycle time" power history was similar to the standard history, but the assembly was removed from the core during the three cycles and then replaced for the fourth cycle. The "variable power" history was the standard history but with $80 \%$ of full power during cycle two and $120 \%$ of full power during cycle three.

Two major changes were made to CINDER-PC to improve this comparison and make use of the modern computers now available.

- The original user interface was a commercial package that will not run on a modern computer. A new user interface was written.

- KAFKA routinely gives atom densities for more nuclides than CINDER-PC, so to enhance the comparison, we extended CINDER-PC to include these additional nuclides. More "chains" outlining the growth and depletion of these new nuclides were added and the output extended. A total of 21 nuclides were used, ranging from ${ }^{234} \mathrm{U}$ through ${ }^{246} \mathrm{Cm}$.

Other, more minor, modifications were also made.

Our group also had available the ORNL burnup code for a PC called ORIGEN2, so we installed it and learned how to use it. Results from all three codes could then be compared.

During a visit to Cadarache to compare results, some differences in the assumed conditions were uncovered (such as the half-life for spontaneous fissioning of ${ }^{246} \mathrm{Cm}$ and the amounts of ${ }^{234} \mathrm{U}$ and ${ }^{236} \mathrm{U}$ initially present) and rectified by new KAFKA calculations to exactly match those used with CINDER-PC and ORIGEN2.

The results from the three codes generally agree rather well, but there were a few interesting exceptions. Neutron emission rates were calculated from the codes' atom densities, but their comparisons tracked the comparisons of the atom densities, implying that the fundamental neutron production data sets are equivalent.

CINDER-PC consistently gave ${ }^{234} \mathrm{U}$ atom densities that were only about $20 \%$ of those from the other two codes. This nuclide is produced from the alpha decay of ${ }^{238} \mathrm{Pu}$, which itself is another case where CINDER-PC differs from the other two codes; the atom densities for ${ }^{238} \mathrm{Pu}$ from CINDER-PC are about $75 \%$ of those from ORIGEN2 and KAFKA. (For the other isotopes of plutonium, the agreement among the three codes is quite good, especially between CINDER-PC and KAFKA.) The same half-life for ${ }^{238} \mathrm{Pu}$ was used by the codes, so the reason for lower CINDER-PC atom densities is not known at this time; if it were the result of the lower production of ${ }^{238} \mathrm{Pu}$, the atom densities from CINDER-PC would be lower by only $25 \%$, not $80 \%$. But the neutron production rate from ${ }^{234} \mathrm{U}$ is not significant for safeguards work, so this disagreement is of no immediate importance.

For all but very-low-burnup fuel, the most important sources of neutrons are isotopes of curium, notably ${ }^{242} \mathrm{Cm}$ and ${ }^{244} \mathrm{Cm}$. The half-life of ${ }^{242} \mathrm{Cm}$ is only 163 days while that of ${ }^{244} \mathrm{Cm}$ is 18.11 years, so after a couple of years of cooling the neutron production rate is dominated by ${ }^{244} \mathrm{Cm}$. However, in this comparison there were some low burnups $(15 \mathrm{GWd} / \mathrm{tU})$ and the cooling time was only 495 days, so ${ }^{242} \mathrm{Cm}$ was not negligible. Figure 3 shows how the ${ }^{244} \mathrm{Cm}$ fraction of neutrons varies with burnup, initial enrichment, and power history. (Note that the data for the 


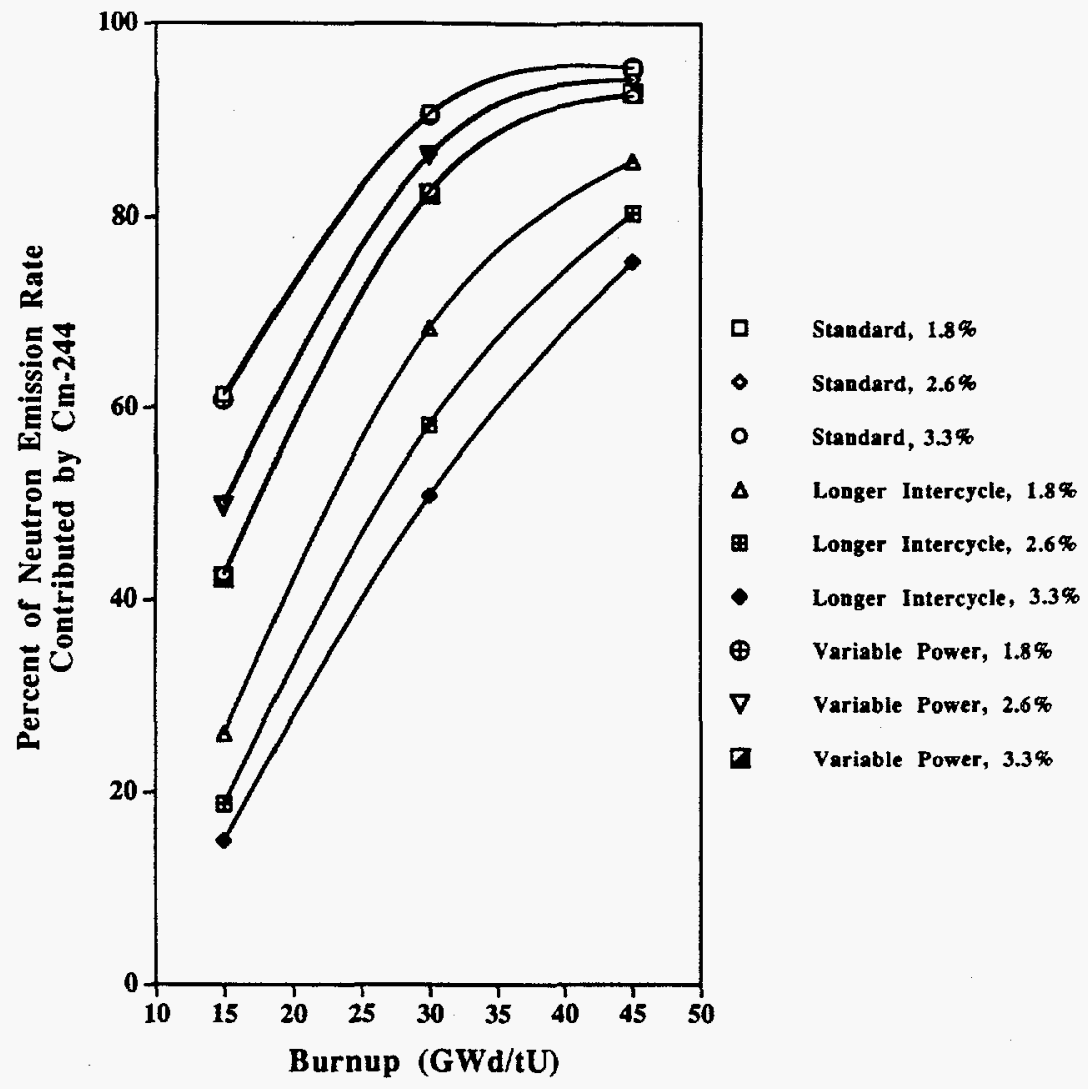

Fig. 3. Percentage of neutron emission rate contributed by ${ }^{244} \mathrm{Cm}$ as a function of burnup and different irradiation history.

standard and variable power histories are identical, while those for the longer intercycle case are lower because of the additional time for decays.)

The curium atom densities from CINDER-PC were consistently smaller than those from KAFKA (ORIGEN2 densities varied less regularly about CINDER-PC and KAFKA values). The ratio of CINDER-PC and KAFKA densities ranged monotonically from about 0.90 for ${ }^{242} \mathrm{Cm}$ to about 0.50 for ${ }^{246} \mathrm{Cm}$. We suspect that the two codes are using one or more different capture cross sections that affect the production of ${ }^{242} \mathrm{Cm}$, but this could not be verified immediately. (CINDER-PC uses cross sections for four energy groups; KAFKA has one-group cross sections for various burnups.) A small change in the production of ${ }^{242} \mathrm{Cm}$ will have increasingly larger effects on the isotopes of curium with larger atomic weights because of the multiple numbers of neutron captures involved. But the ratios of ${ }^{244} \mathrm{Cm}$ atom densities from CINDER-PC and KAFKA were virtually the same for the 27 cases (0.76), so the difference between CINDER-PC and KAFKA atom densities for ${ }^{244} \mathrm{Cm}$ is only a constant multiplier and can be absorbed in the $\alpha$ parameter in Eq. (2). The fraction of the total neutron emission rate that is contributed by ${ }^{244} \mathrm{Cm}$ is the same from CINDER-PC and KAFKA calculations (as shown in Fig.4), which is the value needed to use Eq. (2). The comparison of these burnup codes confirms the use of CINDER-PC to calculate the ${ }^{244} \mathrm{Cm}$ fraction needed for $\mathrm{Eq}$. (2). The cause of differences in absolute atom densities of curium isotopes among the codes needs to be discovered, but it seems unlikely that it will have any effect on the usefulness of CINDER-PC in these spent-fuel applications. 
Fig. 4. Ratios of CINDER-toKAFKA calculations of ${ }^{244} \mathrm{Cm}$ neutron emission fractions as a function of initial enrichment and burnup.

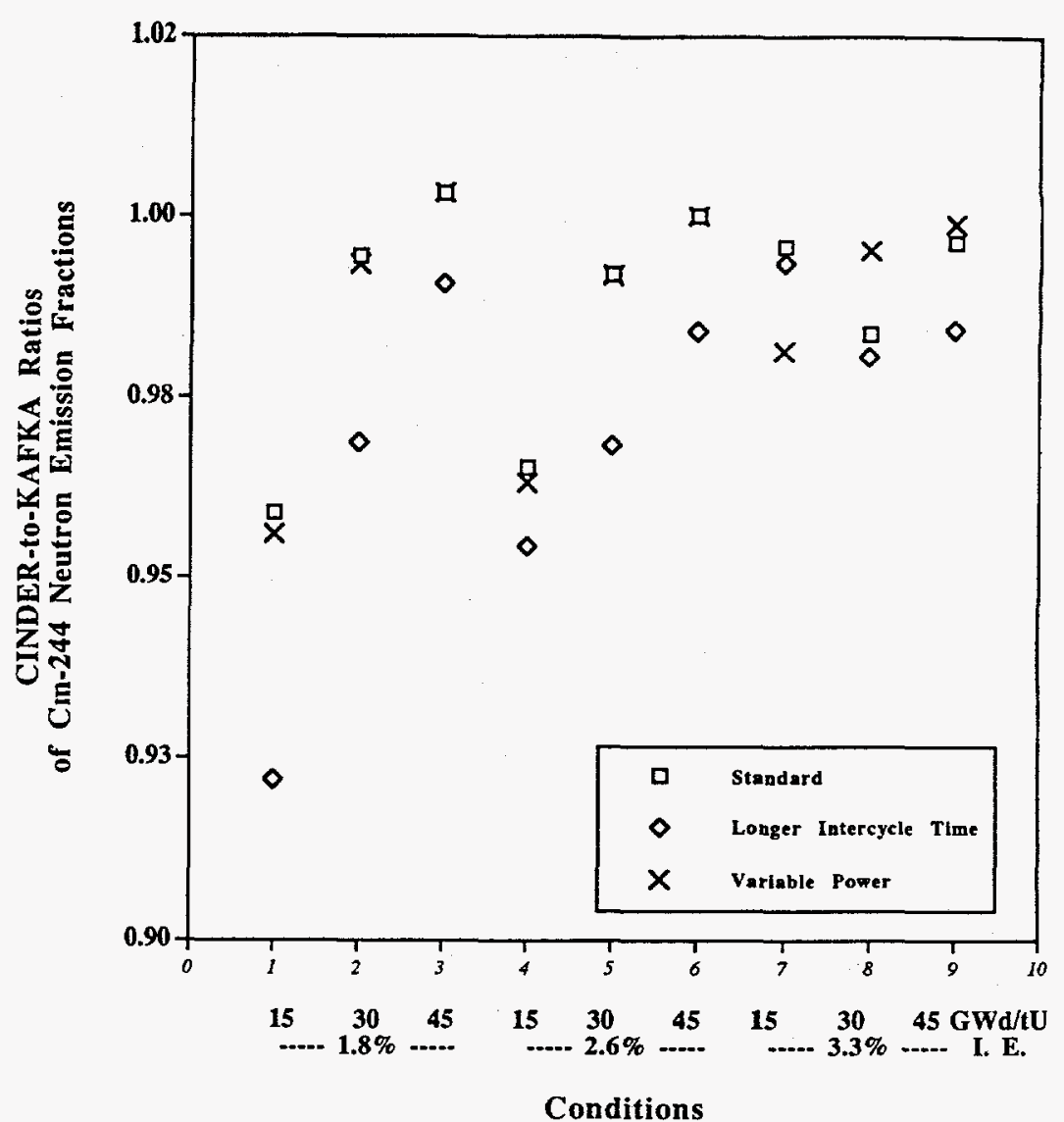

\section{REFERENCES}

1. J. R. Phillips, G. E. Bosler, J. K. Halbig, S. F. Klosterbuer, H. O. Menlove, and P. M. Rinard, "Experience Using a Spent Fuel Measurement System," Nucl. Mater. Manage. XII (Proc. Issue), 175-181 (1983).

2. P. N. Luke, "Single-Polarity Charge Sensing in Ionization Detectors Using Coplanar Electrodes-Application to Semiconductor Detectors," presented at the IEEE Nuclear Science Symposium, Norfolk, Virginia, October 30-November 5, 1994.

3. Radiation Monitoring Devices, Inc., 44 Hunt Street, Watertown, MA 02172.

4. P. M. Rinard and G. E. Bosler, "Safeguarding LWR Spent Fuel with the Fork Detector," Los Alamos National Laboratory report LA-11096-MS (ISPO-281) (March 1988).

5. G. E. Bosler, P. M. Rinard, S. F. Klosterbuer, and J. Painter, "Automated Methods for RealTime Analysis of Spent-Fuel Measurement Data," Nucl. Mater. Manage. XVII (Proc. Issue), 487-493 (1988).

6. T. R. England, "CINDER - A One-Point Depletion and Fission Product Program," Westinghouse Electric Corp. report WAPD - Tm- 334 (1962, Rev. 1964). 
6. T. R. England, "CINDER - A One-Point Depletion and Fission Product Program," Westinghouse Electric Corp. report WAPD - Tm- 334 (1962, Rev. 1964).

7. T. R. England, R. Wilczynski, and N. L. Whittemore, "CINDER-7: An Interim Report for Users," Los Alamos Scientific Laboratory report LA-5885-MS (April 1975).

8. T. R. England, W. B. Wilson, and M. G. Stamatelatos, "Fission Product Data for Thermal Reactors, Part 1: A Data Set for EPRI-CINDER Using ENDF/B-IV," Electric Power Research Institute report EPRI NP-356, Part 1 (December 1976). Also published as Los Alamos Scientific Laboratory report LA-6745-MS (December 1976).

9. T. R. England, W. B. Wilson, and M. G. Stamatelatos, "Fission Product Data for Thermal Reactors, Part 2: Users Manual for EPRI-CINDER Code and Data," Electric Power Research Institute report EPRI NP-356, Part 2 (December 1976). Also published as Los Alamos Scientific Laboratory report LA-6746-MS (December 1976). 